JURNAL SENI MUSIK

http://iournal.unnes.ac.id/sju/index.php/ism

\title{
PERAN PELATIH DALAM MEMBANGUN PELATIHAN PADUAN SUARA YANG MENYENANGKAN DI PADUAN SUARA VOICE OF CONSERVATION (VOC) UNIVERSITAS NEGERI SEMARANG
}

\section{Cessna Kurniawan}

\section{Suharto}

\section{Eko Raharjo}

Jurusan Pendidikan Sendratasik, Fakultas Bahasa dan Seni, Universitas Negeri Semarang, Indonesia

\section{Info Artikel \\ Sejarah Artikel: \\ Diterima Oktober 2018 \\ Disetujui Maret 2019 \\ Dipublikasikan Maret \\ 2019}

\section{Kata Kunci}

Peran, Pelatihan, pendekatan, psikologi, Paduan suara.

Keyword:

Role, training, approaches, psychology, choir

\begin{abstract}
Abstrak
Paduan suara Voice Of Conservation (VOC) merupakan salah satu unit kegiatan mahasiswa (UKM) di Universitas Negeri Semarang yang anggotanya adalah gabungan mahasiswa dari berbagai fakultas yang ada di UNNES. VOC terdiri dari banyak orang yang memiliki karakter yang berbeda. Walaupun begitu, VOC tetap berprestasi dalam skala nasional maupun internasional. Dengan banyaknya prestasi yang dicapai, tentu tujuan dari penelitian ini adalah untuk mengetahui bagaimana peran pelatih dan apa saja yang dilakukan pelatih sehingga paduan suara Voice Of Conservation bisa berprestasi. Penelitian ini menggunakan pendekatan deskriptif kualitatif. Pengumpulan data melalui observasi, wawancara dan dokumentasi. Teknik analisis data yang digunakan adalah penyajian data, reduksi data, dan kesimpulan. Hasil dari penelitian ini menunjukkan bahwa dalam proses latihan, pelatih akan memposisikan dirinya menjadi seperti pemimpin, sahabat, dan orang tua bagi anggota paduan suara. Itu semua adalah wujud dari pemahaman pelatih tentang pentingnya memahami sisi psikologis anggota dengan memandang dari segi ilmu psikologi.

\section{Abstract}

Voice Of Conservation (VOC) choir is one of the student activity units (UKM) at Semarang State University whose members are a combination of students from various faculties at UNNES. VOC consists of many people who have different characters. However, VOC still achieves on a national and international scale. With the many achievements achieved, of course the purpose of this research is to find out how the coach looks and what the coach does so that the Voice Of Conservation choir can achieve. This research use desciptive qualitative approach. Collecting data through observation, interviews and documentation. Data analysis techniques used are data presentation, data reduction, and conclusions. The results of this study indicate that the trainer uses a psychological approach and pays more attention to psychological factors in the training process. In practice, the trainer will position himself as a leader, friend, and parent for the choir members. There are several psychological factors that also affect the process and results of training such as sense or feeling, mentality, confidence, and fear.
\end{abstract}

(C) 2019 Universitas Negeri Semarang

\footnotetext{
Jurusan Pendidikan Sendratasik, FBS

Universitas Negeri Semarang, Indonesia

Email: usmanwafa@mail.unnes.ac.id
}

ISSN 2301-6744 


\section{PENDAHULUAN}

Seni sebagai suatu bentuk ekspresi yang memiliki sifat-sifat kreatif, emosional, individual, abadi dan universal. Sesuai dengan salah satu sifat seni yakni kreatif, maka seni sebagai kegiatan manusia selalu melahirkan kreasi-kreasi baru, mengikuti nilai-nilai yang berkembang di masyarakat. Seperti yang kita ketahui, bahwa kebutuhan terhadap seni sudah menjadi naluri manusia, karena pada prinsipnya manusia menyukai sesuatu yang indah, enak untuk dilihat., dan di dengar. Pandangan itu akan lebih indah dan sempurna bila disertai alunan suara. Karena kesenangan itulah, muncul pandangan seni sebagai alat yang tidak pernah lepas dari kehidupan manusia, seni musik khususnya.

Musik merupakan bahasa yang universal, karena musik mampu di mengerti dan dipahami oleh setiap orang dari bangsa apapun di dunia ini. Tidak bisa dipungkiri bahwa musik telah berada di sekeliling kehidupan manusia sejak manusia itu sendiri berada dalam kandungan ibu-nya. Beberapa ahli menyatakan bahwa musik adalah suatu hasil karya, cipta, rasa manusia yang tak terlihat, tapi dapat didengar dan dirasakan, kemudian ditampilkan dalam suatu event pertunjukan dan disaksikan oleh berbagai kalangan, yakni oleh penikmat musik, pengamat musik dan masyarakat awam (Dick \& Careway, 2009: 4). Musik memiliki peranan yang sangat penting bagi kehidupan manusia sehari-hari sesuai dengan fungsi dan kegunaannya masingmasing. Kita juga mengenal fungsi musik diantaranya sebagai media hiburan, media ritual, media pengobatan, pendidikan sebagai media informasi dan lain sebagainya.

Musik dalam kehidupan sosial dapat dipelajari secara formal dan non formal, atau informal melalui bidang pendidikan. Menurut Tirtaraharja (1990 : 1315), yaitu :

"Pendidikan terbagi menjadi tiga bagian, yaitu pendidikan formal, pendididan informal, dan pendidikan non formal. Pendidikan formal adalah pendidikan yang sengaja dirancang dan dilaksanakan dengan aturan-aturan yang ketat, seperti harus berjenjang dan berkesinambungan. Pendidikan informal adalah pendidikan yang terjadi dalam lingkungan keluarga yang berlangsung alamiah dan wajar. Pendidikan non formal adalah pendidikan di lingkungan masyarakat (salah satu contohnya adalah kursus dan kelompok belajar) tidak dipersyaratkan berjenjang dan berkesinambungan, serta dengan aturan-aturan yang lebih longgar ".

Berdasarkan uraian tersebut, musik dalam kehidupan sosial yang dapat kita pelajari dengan pendidikan non formal salah satunya adalah mengikuti pelatihan paduan suara. Pelatihan paduan suara ini bisa kita lakukan pada kelompok-kelompok atau organisasi-organisasi tertentu dalam bidang paduan suara. Paduan suara adalah nyanyian bersama dalam beberapa suara. Biasanya nyanyian bersama itu dalam delapan suara, empat suara, tiga suara, atau paling sedikit dua suara (Jamalus, 198: 95). Pada umumnya, paduan suara memuat empat suara, tetapi bisa juga delapan suara (Syafiq, 2003: 225). Dalam Kamus Musik, paduan suara adalah satuan vokal yang dalam penampiannya berbagi menjadi beberapa jalur suara, masing-masing yaitu suara sopran, alto, tenor, dan bass (SATB).

Di Universitas Negeri Semarang terdapat salah satu organisasi yang berkaitan dengan musik, dalam hal ini adalah paduan suara, yaitu Unit Kegiatan Mahasiswa (UKM) Paduan Suara yang diberi nama Voice Of Conservation (VOC). VOC merupakan salah satu unit kegiatan mahasiswa (UKM) yang anggotanya terdiri dari gabungan mahasiswa berbagai fakultas dan jurusan yang ada di UNNES. Anggota VOC juga meliputi mahasiswa dari berbagai semester, dari semester satu sampai semester empat belas.

UKM paduan suara VOC telah menjadi suatu wadah dimana setiap individu berlatih untuk memiliki suatu tujuan yang sama, prestasi dalam paduan suara misalnya. Dalam proses mencapai prestasi tersebut tentu ada banyak rintangan yang akan dihadapi oleh tim. Berbeda karakter, sifat, mental, bahkan berbeda kemampuan, memang menjadi suatu hal yang cukup rumit. Dibutuhkan kerjasama yang baik antara seluruh elemen agar kelompok tersebut benar-benar mencapai apa yang ingin dituju. Namun kembali lagi pada sebuah kenyataan bahwa dalam sebuah kelompok itu pasti memiliki karakteristiknya masing-masing. Berbeda antara satu individu dengan individu lain merupakan tantangan yang cukup serius dalam sebuah kelompok paduan suara.

Sebagai sebuah kelompok paduan suara, tentu setiap elemen paduan suara memiliki perannya masing-masing. Sebagai upaya untuk meningkatkan kualitas bernyanyi paduan suara VOC mengadakan latihan vokal (latihan bernyanyi). Setiap individu diajar untuk bernyanyi dan setiap individu wajib untuk bisa bernyanyi. Sementara setiap individu tentu memiliki kemampuan dan kualitas yang berbeda-beda. Dalam proses latihan pun tentu ada seorang pelatih yang akan mengajarkan kelompok paduan suara itu sampai benar-benar bisa bernyanyi dengan baik. Sementara itu, dengan adanya perbedaan dari setiap inividu, pelatih harus menyusun strategi agar apa yang diinginkan dapat tercapai dengan baik. Dalam hal ini pelatih harus mengerti dan benar-benar paham akan karakter setiap anggota paduan suaranya agar sang pelatih 
dapat memberikan perlakuan, pengajaran yang sesuai dan tepat sasaran.

Setiap perilaku atau tindakkan yang dilakukan oleh pelatih akan mempengaruhi atau pasti berdampak pada anggota paduan suara yang dipimpin. Begitu pula sebaliknya, setiap perilaku anggota akan sangat berdampak pada keberhasilan paduan suara tersebut. Misalnya dari sisi pelatih, ada pelatih yang dekat dengan semua orang yang dilatihnya dan pasti perkembangan paduan suara itu akan baik, karena ada kenyamanan didalamnya. Ada juga pelatih yang cuek atau bahkan hanya dekat dengan beberapa orang, pasti perkembangannya akan terhambat karena terjadi ketidak cocokkan. Contohnya dari sisi penyanyi, ada penyayi yang memiliki karakter bandel dan keras kepala, pasti itu akan sangat mempengaruhi proses latihan dan juga hasil. Begitu sebaliknya, jika setiap individu dalam kelompok paduan suara memiliki karakter yang baik dan mau mendengar arahan pelatih maka, pasti mempengaruhi selama proses dan hasilnya pun pasti akan berbeda.

VOC unnes memiliki kualitas bernyanyi yang cukup baik. Terbukti dengan adanya prestasi-prestasi yang diraih oleh kelompok ini. Beberapa prestasi yang pernah diraih antara lain:

1) Tahun 2015 VOC meraih medali perak dalam Festival Paduan Suara 2th ITB International Choir Competition.

2) Tahun 2015 VOC meraih medali emas (the winner on pop \& jazz category) dan perak dalam ajang 4th Bali International Choir Festival.

3) Tahun 2015 VOC menjadi winner dalam kategori Pop and Jazz di 4th Bali International Choir Festival.

4) Tahun 2016 VOC meraih medali Emas dalam kategori Folklore pada Lomba Paduan Suara LPS 9 Saptagita USM.

5) Tahuan 2017 VOC meraih 2 medali emas dalam 6th Bali International Choir Festival kategori Folklore dan Scenic Folklore.

6) Tahun 2017 VOC mendapatkan kesempatan sebagai delegasi Indonesia untuk memperkenalkan kekayaan budaya Indonesia melalui sajian paduan suara dalam 2017 Hainan (21st-Century Maritime Silk Road) Choir Festival.

7) Tahun 2017 VOC meraih 2 Gold Award dalam kategori Pop and Jazz dan Mixed Choir di 2017 Hainan (21st-Century Maritime Silk Road) Choir Festival.

Prestasi-prestasi tersebut, diraih oleh VOC dengan penuh kerja keras dan dukungan dari berbagai faktor. Salah satu faktor tersebut adalah peran seorang pelatih dalam proses latihan. Dalam kehidupan paduan suara, seringkali dihadapkan pada suatu keadaan dimana sifat, sikap, watak, emosi, perasaan, dan karakter dari masing-masing individu akan muncul. Maka dari itu, agar berhasil dalam proses latihan sangat dibutuhkan peran pelatih dengan memahami anggota dari sisi psikologi. Ini merupakan upaya untuk meningkatkan kualitas paduan suara dengan menyentuh sisi kehidupan internal yaitu keadaan jiwa.

Kata psikologis memang sering kita dengar, namun ketika berbicara tentang psikologis, sudah pasti ada banyak sudut pandang tentang hal itu. Dalam KBBI (Kamus Besar Bahasa Indonesia) menjelaskan bahwa psikologis adalah sesuatu yang berkenaan dengan psikologi; bersifat kejiwaan. Psikologis dapat diartikan sebagai kejiwaan manusia.

Akan tetapi, sejak dahulu tidak pernah dijumpai kata sepakat tentang apa yang dimaksud tentang jiwa (soul). Desmita (2015: 1) menyebutkan sejak zaman Yunani kuno, para filsof berusaha mempelajari jiwa. Plato misalnya, mengatakan jiwa adalah ide, Hipocrates berpendapat jiwa adalah karakter, sedangkan Aristoteles mengartikan jiwa sebagai fungsi mengingat. Kemudian pada abad ke-17, Renedescartes, filsof Perancis, berpendapat bahwa jiwa adalah akal atau kesadaran. George Berkeley, filsof Inggris yang hidup di akhir abad ke-17, menyatakan jiwa adalah persepsi. Sementara itu, John Locke, filsof Inggris lainnya, beranggapan bahwa jiwa adalah "kumpulan ide yang disatukan melalui asosiasi”. (Sarwono, 1992)

Berdasarkan uraian di atas, dapat diartikan bahwa ilmu tentang kejiwaan manusia disebut dengan psikologi. Secara spesifik, psikologi lebih banyak dikaitkan dengan kehidupan organisme manusia. Dalam hubungan ini, psikologi didefenisikan sebagai ilmu pengetahuan yang berusaha memahami perilaku manusia, alasan, dan cara melakukan sesuatu, dan juga memahami cara makhluk tersebut berfikir dan berperasaan (Gleitman, 1986).

Menurut Muhibbin (2014:10), dalam ilmu kejiwaan (psikologi), menyebutkan bahwa para ahli pada umumnya lebih banyak menekankan penyidikan terhadap tingkah laku manusia yang bersifat jasmaniah maupun bersifat rohaniah, tingkah laku psikomotor (ranah krasa) bersifat terbuka yang meliputi perbuatan berbicara, duduk, berjalan, dan seterusnya, lalu tingkah laku tertutup yang meliputi berpikir, berkeyakinan, berperasaan dan seterusnya. Kita dapat menarik simpulan bahwa psikologi adalah ilmu pengetahuan yang menyelidiki dan membahas tingkah laku terbuka dan tertutup pada manusia, baik selaku individu maupun kelompok, dalam hubungannya dengan lingkungan. Lingkungan menjadi salah satu faktor yang sangat kuat dalam proses pertumbuhan psikologi. Lingkungan dalam hal ini meliputi semua orang, barang, keadaan, dan 
kejadian yang ada disekitar manusia. Salah satu dari bentuk lingkungan tersebut adalah sekumpulan manusia yang berada dalam satu wadah dan membentuk suatu struktur yang biasanya disebut dengan organisasi.

Menurut peneliti, belum ditemukan penelitian yang membahas tentang "Peran Pelatih Dalam Pelatihan Paduan Suara Dengan Menggunakan Pendekatan Secara Psikologi Di Voice Of Conservation (VOC) Universitas Negeri Semarang”. Namun penelitian yang sejenis dilakukan oleh Priska Yuli Nugraheni Ayudani dalam skripsi yang berjudul "Strategi Pembelajaran Paduan Suara Swara Wadhana, Universitas Negeri Yogyakarta". Penelitian ini bertujuan untuk mendeskripsikan strategi pembelajaran yang digunakan pada kelompok Paduan Suara Mahasiswa "Swara Wadhana" Universitas Negeri Yogyakarta sehingga dapat memperoleh prestasi. Penelitian ini merupakan penelitian deskriptif kualitatif. Fokus permasalahan dari penelitian ini adalah untuk mengetahui bagaimana strategi pembelajaran yang diterapkan pada Paduan Suara Mahasiswa "Swara Wadhana". Data diperoleh dengan teknik observasi, wawancara dan dokumentasi. Data dianalisis dengan teknik analisis data model interaktif. Keabsahan data diperoleh melalui triangulasi data dan kecukupan referensial. Hasil penelitian menunjukkan bahwa terdapat strategi pembelajaran yang dilakukan sebagai program rutin tahunan, yaitu strategi penerimaan warga baru (Penwaru), yang dilakukan dengan tes wawancara dan musikalitas.

Dari penjelasan tersebut, penelitian dari Priska Yuli menjadi acuan peneliti untuk melihat bagaimana strategi pembelajaran yang diterapkan pada Paduan Suara Mahasiswa "Swara Wadhana" dan metode penelitian yang dipakai dalam mengolah data. Peneliti menganggap penelitian-penelitian tersebut relevan dengan penelitian Pendekatan Psikologi dalam Pelatihan Paduan Suara Voice Of Conservation (VOC) di Universitas Negeri Semarang.

Berdasarkan uraian di atas, peneliti menilai bahwa penting bagi tim paduan suara dan terutama bagi pelatih untuk menyadari terdapat pengaruh yang besar dari keadaan jiwa setiap anggota paduan suara itu. Berperan dengan memandang secara psikologi akan sangat menunjang kelompok paduan suara untuk mencapai suatu proses yang lebih bermakna dan tentunya untuk meraih sebuah prestasi yang gemilang. Maka dari itu peneliti tertarik untuk mengambil sebuah judul penelitian "Peran Pelatih Dalam Pelatihan Paduan Suara Dengan Menggunakan Pendekatan Secara Psikologi di Paduan Suara Voice Of Conservation (VOC) Universitas Negeri Semarang".

\section{METODE}

Penelitian ini menggunakan pendekatan deskriptif kualitatif, yaitu penguraian tentang kejadian-kejadian berdasarkan data-data baik tertulis maupun tidak tertulis. Penelitian ini menggambarkan dan menguraikan permasalahan yang berhubungan dengan pendekatan psikologi pada pelatihan paduan suara Voice Of Conservation (VOC) Universitas Negeri Semarang dalam bentuk kalimat, bukan dengan angka-angka (Rachman, 1993: 108). Seperti yang telah peneliti lakukan dalam penelitian ini, peneliti mendeskripsikan hal-hal yang didapat dalam observasi, wawancara, dan dokumentasi.

Metode penelitian pada dasarnya merupakan cara ilmiah untuk mendapatkan data dengan tujuan dan kegunaan tertentu (Sugiyono, 2009: 2). Metode penelitian juga merupakan cara-cara kerja untuk dapat memahami objek penelitian dan merupakan bagian yang penting untuk diketahui oleh seorang peneliti untuk memberikan ketentuan-ketentuan dasar dalam mendekati suatu masalah dengan tujuan menemukan dan memperoleh hasil yang akurat dan benar. Suatu penelitian memperlukan metode penelitian yang dapat dipertanggung jawabkan secara ilmiah. Sumaryanto (2001: 2) menyebutkan bahwa penelitian kualitatif menjadi sebuah tradisi tertentu dalam penelitian sosial yang bersifat fundamental bergantung pada pengamatan manusia dalam kawasannya sendiri dan berhubungan dengan orang-orang tersebut dalam bahasanya dan dalam peristilahannya. Data yang diperoleh peneliti dalam penelitian kualitatif ini, didapat dari berbagai nara sumber yang memberikan informasi tentang data. Dalam penelitian ini, peneliti mendapatkan data-data yang bersifat kualitatif dan berhubungan mengenai pendekatan psikologi pada pelatihan paduan suara Voice Of Conservation (VOC) Universitas Negeri Semarang.

Sumber dan teknik pengumpulan data dalam penelitan disesuaikan dengan fokus dan tujuan penelitian" (Sugiyono, 2014: 181). Dalam penelitian ini, peneliti memperoleh data-data yang diperlukan untuk pelaksanaan penelitian dari sumber data primer maupun sumber data sekunder. Sumber data dibagi menjadi dua bagian yaitu sumber data primer dan sumber data sekunder. Sumber data primer dalam penelitian ini adalah pelatih dan anggota paduan suara Voice Of Conservation (VOC) UNNES. Pelatih dan anggota paduan suara VOC diambil datanya melalui observasi dan wawancara yang dilakukan oleh peneliti. Sedangkan data sekunder pada penelitian kali ini didapat melalui dokumentasi yang dilakukan oleh peneliti dengan cara melakukan pengamatan secara langsung. Datadata diperoleh dari hasil pengamatan secara langsung 
dan ikut berpartisipasi dalam pendekatan psikologi di Voice Of Conservation (VOC) serta mengumpulkan dokumentasi yang dibutuhkan.

Tanpa mengetahui teknik pengumpulan data, peniliti tidak akan mendapatkan data yang memenuhi standar data yang ditetapkan (Sugiyono, 2010: 308). Teknik pengumpulan data pada penelitian ini menggunakan teknik-teknik observasi (pengamatan langsung), wawancara dan dokumentasi yang dilakukan dengan mengacu pada pedoman yang telah dipersiapkan terlebih dahulu dan dikembangkan pada saat pelaksanaannya.

Dalam penelitian kualitatif, analisis data merupakan kegiatan setelah data dari seluruh responden atau sumber data lain terkumpul. Kegiatan dalam analisis data adalah mengelompokan data berdasarkan variable dan jenis responden, mentabulasi data berdasarkan variable dari sekuruh responden, menyajikan data tiap variable yang diteliti, melakukan perhitungan untuk menjawab rumusan masalah, dan melakukan perhitungan untuk menguji hipotesis yang telah diajukan (Sugiyono, 2013: 207).

Menurut Moleong (dalam Sumaryanto, 2014: 43), langkah pertama dalam analisis data disebut deskripsi data. Langkah selanjutnya adalah mengadakan reduksi data dengan jalan membuat abstraksi. Abstraksi merupakan usaha membuat rangkuman yang inti, proses, dan pernyataanpernyataan yang perlu dijaga sehingga tetap berada didalamnya. Kemudian menyusun kedalam satuansatuan. Dan yang terakhir adalah pemeriksaan keabsahan data. Langkah terakhir dalam tahapan analisis data adalah memulai penafsiran data dalam mengolah hasil sementara yang didapat menjadi teori substantive dengan metode tertentu (Sumaryanto, 2014: 43).

\section{HASIL DAN PEMBAHASAN}

Gambaran Umum Lokasi Penelitian

UKM Paduan Suara Mahasiswa (PSM) UNNES, yaitu Voice Of Conservation (VOC) berlokasi di Gedung Unit Kegiatan Mahasiswa (UKM) lantai 2. Gedung UKM ini berada di sebelah barat Gedung Auditorium UNNES, di sebelah gedung PKMU, yaitu di Kampus Sekaran, Gunungpati, Kota Semarang.

Lokasi UKM yang berada di tengah lingkungan kampus menjadikan letaknya strategis (dekat dari tempat tinggal atau dalam hal ini adalah kos) untuk para mahasiswa khususnya anggota VOC Unnes untuk melaksanakan kegiatan organisasi, salah satunya yaitu latihan rutin. Latihan rutin VOC tidak hanya dilakukan di gedung UKM saja, akan tetapi lebih sering melaksnakannya di selasar atau teras Gedung Auditorium UNNES. Hal ini karena keterbatasan ruangan UKM dan perlunya tempat latihan yang luas dan lebih mendukung kelancaran proses latihan tersebut.

Peran Pelatih Dalam Pelatihan Paduan Suara Voice Of Conservation Di Universitas Negeri Semarang

Dalam proses pelatihan di VOC UNNES, pelatih menggunakan berbagai macam cara dan pendekatan dalam berlatih. Sebelum memilih langkah apa yang harus diambil, pelatih melakukan pendalaman atau pendekatan secara khusus terhadap setiap anggota paduan suara untuk mengetahui bagaimana perilaku dan respons setiap anggota. Biasanya beliau mengajak bercerita, berkenalan, nyanyi perorang atau perkelompok suara, dan mengajak diskusi. Beliau juga melihat seberapa ketatnya kegiatan perlombaan yang akan diikuti. Itu semua dilakukan agar pelatih dapat menemukan cara untuk menciptakan latihan yang menyenangkan bagi anggota, supaya dalam proses latihan anggota tidak akan merasa jenuh dan tetap memiliki semangat penuh dalam berlatih. Menurut (Rifa'i dan Catharina, 2012: 169) pembelajaran perilaku tidak lepas dari prinsip bahwa perilaku berubah menurut konsekuensi-konsekuensi langsung. Konsekuensi itu bisa menyenangkan dan bisa juga tidak menyenangkan. Pembelajaran yang menyenangkan akan memperkuat perilaku, sebaliknya pembelajaran yang kurang menyenangkan akan memperlemah perilaku. Seperti yang dikatakan oleh bapak Agus sebagai pelatih kepada peneliti ketika ditanyakan tentang bagaimana pendekatan psikologi yang beliau gunakan. Beliau mengatakan,

"sebelum mulai berlatih, biasanya saya akan melihat dulu siapa yang akan saya latih dan saya akan mendalami atau mempelajari lebih dalam lagi terkait dengan karakter anggota. Menggali informasi tentang mahasiswa yang hendak dibina. Kan bisa jadi ada orang yang selalu memliki ketidak percayaan diri, ada juga yang terlalu merasa percaya diri, ada yang masih individual, ada yang bahkan belum bisa beryanyi dan baru mau belajar, ada juga yang memiliki kebiasaan-kebiasaan bawaan mungkin dari keluarga dan juga lingkungan. Saya rasa, saya harus tahu dulu keadaan anggota yang akan saya latih".

Peran pelatih akan diterapkan sesuai dengan keadaan yang dijumpai dalam proses pelatihan atau saat latihan berlangsung. Setelah proses pengamatan, pelatih lalu akan mengambil langkah dan sikap. Menurut Chaplin (1972) dalam Syah (2014: 110), proses adalah Any change in any object or organism, particularly a behavioral or psychological change, (Proses adalah suatu perubahan yang menyangkut tingkah laku atau kejiwaan). Untuk mencapai proses 
yang optimal, pelatih menggunakan cara-cara yang lebih fokus pada tingkah laku dan kejiwaan anggota dengan memposisikan diri menjadi berbagai peran bagi tim paduan suara itu, yaitu menjadi seorang pemimpin sebagai wujud dari pendekatan secara psikologi saat memahami anggota sedang membutuhkan motivasi, teguran, arahan, bahkan sanksi. Wujud dari pendekatan secara psikologi juga diterapkan dengan berperan menjadi seorang sahabat saat ada anggota yang terlihat murung saat latihan, dan mendengarkan keluhan-keluhan atau masalah yang tengah dihadapi anggota. Wujud yang terakhir adalah berperan menjadi orang tua. Sebagai orang tua, pelatih selalu membangun latihan menjadi nyaman sehingga rasa aman dan rasa cinta dari orang tua bisa dirasakan oleh anggota. Pelatih mengajak diskusi, lalu memberi arahan selayaknya orang tua kepada anggota. Hal itu dilakukan agar proses pelatihan atau proses belajar dapat berjalan dengan baik, menyenangkan, serta memperoleh hasil latihan yang maksimal yaitu prestasi. Untuk mencapai hal tersebut, Rifa'i dan Catharina (2012: 169) mengatakan bahwa, perlu diberikan adanya penguatan (reinforcement) untuk meningkatkan motivasi kegiatan belajar. Pemberian penguatan itu dapat berupa penguat sosial (senyuman, pujian), penguat aktivitas (pemberian mainan), dan penguat simbolik (uang, nilai).

Menjadi Seorang Pemimpin

Pelatih akan berperan sebagai sebagai pemimpin artinya harus memiliki 3 sikap, yaitu : (1) wibawa; (2) ketegasan; dan (3) otoritas atau wewenang. Menurut pak Agus, memiliki wibawa artinya memiliki aura sebagai pemimpin yang disegani oleh anggota. Ketegasan berarti memiliki kemampuan untuk mengatur dan mengarahkan tim untuk menuju suatu tujuan. Dengan ketegasan yang dimiliki oleh seorang pemimpin akan menimbulkan rasa tanggungjawab terhadap setiap anggota, dalam hal ini adalah anggota paduan suara. Sikap yang ketiga yaitu memiliki otoritas atau wewenang berarti pelatih memiliki kuasa untuk memutuskan dan melakukan sesuatu sesuai dengan kebutuhan tim dan kebijakan pemimpin. Pelatih juga akan berperan sebagai pemimpin ketika merasa tim itu perlu diberi motivasi, contoh kepemimpinan, semangat juang, teguran, dan diberi jalan keluar jika ada masalah yang dihadapi kelompok paduan suaranya. Pelatih tidak hanya memikirkan tentang teknik vokal saja. Saat saya bertanya tentang "menjadi pemimpin" kepada bapak Agus, beliau menjawab:

"Kita harus selalu seperti itu Ces. Tidak bisa dipungkiri bahwa dalam sebuah tim pasti kadang ada masalah yang dapat membuat paduan suara itu tampil tidak baik. Kadang ada juga saat mereka merasa jenuh menghadapi rintangan yang dihadapi.
Disinilah saya mengambil peran sebagai pemimpin mereka. Saat latihan, saya memberi motivasi yang lebih dan memberi pencerahan tentang sebuah masalah kepada tim. Ini saya lakukan agar mereka tetap solid dan tidak menyerah dalam menghadapi masalah yang dihadapi. Kadang saya juga menegur anggota ketika melakukan kesalahan dan tugas saya sebagai pemimpin ya memberi nasihat atau teguran agar mereka tidak melakukan kesalahan lagi. Bahkan kadang saya menerapkan sistem sanksi, misal kepada anggota yang jarang latihan atau terlambat latihan tanpa izin. Sanksi yang diberikan bervariasi sesuai tingkat kesalahan yang dilakukan, tapi bukan sanksi secara fisik. Saya juga tegas terhadap kesesuaian dengan partitur. Saya ingin enggota bernyanyi sesuai dengan permintaan pertitur. Ketika ada yang bercanda saat latihan, maka saya punya hak untuk memberi teguran bahkan sanksi karena saya memiliki otoritas".

Bapak Eko Agus Kandung berperan sebagai pemimpin agar setiap anggota di VOC UNNES bisa benar-benar memahami cara melatih dan keinginan beliau. Bernyanyi dalam paduan suara harus selalu satu komando atau terpimpin.

Hal ini sehubungan dengan konsep kepemimpinan yang dicetuskan oleh $\mathrm{Ki}$ Hajar Dewantara, yakni Ing Ngarsa Sung Tuladha, Ing Madya Mangun Karsa, Tut Wuri Handayani (Wawan Susetya:2007).

1. Ing Ngarso Sung Tuladha "Di Depan memberi contoh"

Kata "tulodo" pada semboyan ini memiliki arti teladan. Itu artinya seorang pemimpin harus dapat memberikan teladan atau harus dapat menjadi panutan. Kita harus dapat memberikan contohcontoh yang baik terhadap orang-orang sekitar.

2. Ing Madyo Mangun Karsa "Di Tengah memberi Semangat"

Kata " Mangun" memiliki arti membangun sedangkan kata "Karso" memiliki arti niat. Jadi,maksudnya guru harus dapat memberikan inspirasi/motivasti berupa ide ketika berada diantara murid.

3. Tut Wuri Handayani "Di Belakang memberi Dorongan". Semboyan ini memiliki maksud seorang guru harus dapat memberikan dorongan dan juga arahan. Kata "Handayani" disini memiliki arti memberikan dorongan.

Contoh menjadi seorang pemimpin sering kali dilakukan pelatih dalam proses latihan. Saat latihan berlangsung, pelatih selalu memberikan motivasi agar anggota tetap semangat dalam sebuah proses latihan. Ketika ada kendala yang dihadapi pelatih juga turut memberi pandangan dan jalan keluar untuk masalah tersebut. Kadang pelatih juga memberikan teguran saat beberapa anggota 
melakukan kesalahan dan melanggar aturan latihan yang telah disepakati bersama. Tidak hanya teguran, sanksi pun diterapkan misalnya, menyuruh pemanasan sendiri saat terlambat hadir di tempat latihan atau bahkan kadang tidak mengizinkan anggota yang terlambat untuk ikut berlatih bersama tim. Hal ini dilakukan supaya anggota lebih disiplin dan belajar bertanggung jawab dengan apa yang telah disepakati.

Menjadi Seorang Sahabat

Sebagai seorang pelatih, pak Agus merasa perlu untuk menjadi sahabat bagi setiap anggota paduan suara yang dilatih. Dalam hal ini beliau menjadi pendengar yang baik untuk masalah-masalah atau hal apa saja yang membuat setiap individu atau tim terganggu dalam proses latihan. Pelatih merangkul anggota yang sedang bersedih, dan lebih mengerti suasana jiwa anggota. Seperti yang dikatakan beliau pada saat wawancara, yaitu

"Kita harus mengetahui sisi psikologis masingmasing anak. Kalau dia sedih kita rangkul, dalam hal ini yaitu kita beri mereka kenyamanan untuk mereka mau menceritakan permasalahannya kepada kita. Seorang sahabat kita tidak akan meninggalkan siapapun dia yang sedang merasa sedih. Dalam hal ini banyak hal yang perlu saya lakukan sebagai seorang sahabat, bukan seorang pemimpin, yaitu dengan cara kita lebih rileks, lebih mengerti kondisi jiwa mereka".

Selain itu, beliau sering mengajak anggota paduan suara untuk bercanda baik secara langsung maupun dalam sebuah jejaring sosial. Misalnya, pada jejaring sosial Instagram dan Facebook. Bila salah satu dari anggota ataupun pak Agus sendiri mengunggah sebuah postingan foto dan video, mereka saling mengomentari dengan nada percakapan bercanda, saling melontarkan kata dan kalimat yang memberi semangat, motivasi, dan apresiasi.

Menurut pelatih, menjadi seorang sahabat adalah cara agar antara pelatih dan anggota tetap terjalin hubungan yang baik dan memiliki rasa nyaman dalam berlatih sehingga apa yang diajarkan bisa tersampaikan dengan baik. Akan tetapi, pelatih juga membatasi atau dengna kata lain bisa menempatkan diri di mana pelatih menjadi sahabat, di mana pelatih menjadi seorang pemimpin dan orang tua.

Hal ini sejalan dengan Rubin (2004), persahabatan adalah multidimensi dalam sifat dan melayani manusia dalam berbagai cara (seperti kesenangan, harapan dan ketakutan, menyediakan afeksi, dukungan dan keamanan emosi).

Dalam beberapa khasus, saat proses latihan paduan suara, dari sejak mulainya latihan sampai menjelang istirahat latihan, ada seorang anggota yang terlihat murung dan merengut wajahnya. Lalu pak Agus hadir sebagai seorang sahabat dan dia menjadi pendengar yang baik. Ternyata anggota tersebut mengalami sakit atau kurang enak badan. Akhirnya pak Agus pun menyuruhnya pulang dan diizinkan untuk tidak mengikuti latihan serta diberi perhatian khusus dengan memberikan penguat berupa senyuman dan sentuhan.

\section{Sebagai Orang Tua}

Seorang pelatih yang memposisikan dirinya sebagai orang tua adalah bagaimana pelatih dapat memperlakukan anggota seperti anak sendiri. Dengan begitu setiap anggota akan merasa tidak hanya memiliki orang tua kandung di rumah, tetapi mereka memiliki orang tua di tempat latihan sehingga setiap anggota merasa paduan suara adalah rumah bagi mereka. Mereka dapat merasa mendapatkan kasih sayang, merasa terlindungi dan bahkan betah dalam mengikuti setiap kegiatan di paduan suara. Seperti yang dikatakan oleh pak Agus pada saat peneliti melakukan wawancara, yaitu beliau mengatakan,

"Dari sisi sebagai orang tua, kita bisa mengerti kebutuhan daripada anak. Sehingga ketika kita memberikan nasihat, kita menempatkan diri sebagai orang tua, bukan menjadi sahabat lagi. Kita bisa menempatkan diri kapan menjadi sahabat, kapan menjadi orang tua. Kalo menjadi seorang orang tua, betul-betul kita seperti menjadi ora tua mereka sendiri, kita ajak diskusi, kita berikan stimulus, kita berikan kasih sayang kepada mereka. Hal itu harus kita terapkan supaya mereka merasa memiliki orang tua selain orang tua kandung di rumah. Sehingga segala sesuatu mereka bisa curhat bisa minta nasihat".

Pernyataan dari pak Agus tersebut diperjelas lagi dari pendapat Semiawan dan kawan-kawan menyatakan, "Orang tua perlu menciptakan lingkungan rumah atau keluarga yang serasi, selaras, dan seimbang dengan kehadiran anak-anak berbakat. Disamping itu perlu menyiapkan sarana lingkungan fisik yang memungkinkan anak mengembangkan bakatnya. Perlu sikap demokrasi juga dalam memberikan banyak larangan, dirangsang untuk menjadi mandiri dan percaya diri." (Semiawan, 1990 :31-55)

Salah satu contoh dimana pak Agus memposisikan dirinya sebagai orang tua yaitu pada saat latihan, pak Agus menjadi lebih dekat dengan anggota dan membuat suasana latihan menjadi seperti ada di "rumah" sendiri. Anggota pun terlihat leluasa untuk bertanya, bercerita, bercanda, tertawa, dan melakukan sesuatu. Ketika ada yang salah pun, pelatih tidak segan untuk menegur dan membimbing kearah yang lebih baik dan benar. Bahakan sesekali 
beliau memberi perhatian dengan melakukan sesuatu melalui sentuhan seperti berjabat tangan dan merangkul.

\section{SIMPULAN DAN SARAN}

Berdasarkan hasil penelitian dan pembahasan yang telah dipaparkan mengenai Peran Pelatih Dalam Pelatihan Paduan Suara Dengan Menggunakan Pendekatan Secara Psikologi di Paduan Suara Voice Of Conservation (VOC) Universitas Negeri Semarang disimpulkan bahwa dalam proses pelatihan, pelatih melakukan pendalaman atau pendekatan terlebih dahulu terhadap setiap anggota paduan suara yang akan dilatih untuk mengetahui perilaku dan respons dari anggota. Pelatih akan berperan menjadi seorang pemimpin, sahabat, dan orang tua bagi anggota sebagai wujud dari pendekatan secara psikologi yang dilakukan pelatih.

Pelatih berperan sebagai sebagai pemimpin artinya harus memiliki 3 sikap, yaitu : (1) wibawa; (2) ketegasan; dan (3) otoritas atau wewenang. Selain itu, pelatih juga akan memposisikan diri menjadi seorang sahabat. Dalam hal ini beliau menjadi pendengar yang baik untuk masalahmasalah atau hal apa saja yang membuat setiap individu atau tim terganggu dalam proses latihan. Pelatih merangkul anggota yang sedang bersedih, dan lebih mengerti suasana jiwa anggota. Kemudian yang terakhir adalah pelatih memposisikan diri sebagai orang tua, yaitu pelatih dapat memperlakukan anggota seperti anak sendiri sehingga setiap anggota merasa paduan suara adalah rumah bagi mereka. Mereka dapat

merasa mendapatkan kasih sayang, merasa terlindungi dan bahkan betah dalam mengikuti setiap kegiatan di paduan suara.

Penulis menyampaikan terima kasih kepada:

1. Prof. Dr. Fathur Rokhman, M.Hum. Rektor Universitas Negeri Semarang yang telah memberikan kesempatan kepada penulis menempuh studi di Universitas Negeri Semarang.

2. Prof. Dr. M. Jazuli, M.Hum. Dekan Fakultas Bahasa dan Seni yang telah memberikan izin kepada penulis untuk penelitian.

3. Dr. Udi Utomo, M.Si. Ketua Jurusan Pendidikan Seni Drama, Tari, dan Musik yang telah memberikan persetujuan tema yang baik.

4. $\neg \neg$ Dr. Suharto, S.Pd., M.Hum Dosen Pembimbing 1 dan Drs. Eko Raharjo, M.Hum. Dosen Pembimbing II yang telah banyak memberikan bimbingan selama proses penyusunan Skripsi dan Artikel Jurnal.

5. Anggota dan pengurus paduan suara Voice Of Conservation, dan pelatih paduan suara VOC, serta pembina VOC selaku Objek Penelitian yang telah memberikan data, informasi, keterangan, dan penjelasan terkait dengan kebutuhan penyusunan Jurnal sekaligus memberikan pengalaman yang sangat berharga kepada penulis.

6. Rekan-rekan yang telah membantu dalam proses penyusunan Jurnal.

\section{DAFTAR PUSTAKA}

C.P. Chaplin, 1995. Kamus Psikologi, terj, Kartini Kartono. Jakarta: PT grafindo Persada.

Dick, W., Carey, L., dan Carey, J.O. (2009) The Systematic Design of Instruction. New Jersey: Pearson

Gleitman, Henry. 1989. Psychology. 2nd Edition. New York: W.W. Norton \& Company.

Gulo \& Kartono, K. 1987. Kamus Psikologi. Bandung: CV. Pionir Jaya.

Jamalus dan A. T. Mahmud. 1981. Musik IV untuk SPG. Jakarta: Departemen Pendidikan dan Kebudayaan.

Langgulung, Hasan. 1992. Teori-teori Kesehatan Mental. Jakarta: Pustaka Al-Husna.

Lauster, Peter. 2002. Tes Kepribadian. Jakarta: Bumi Aksara

Rachman, Maman., 1993. Langkah-langkah Penelitian Pendidikan. Semarang: IKIP Press.

Rubin, Kenneth H. Dwyer. Kathleen M. Kim, Angel H., \& Burgess, Kim B. (2004). Attachment, friendship, and psychological functioning in early adolescence. The Journal Early Adolescence, 24 (4), 326-356.

Soelasmono, Yudho. 2011. Mengubah Ketakutan Menjadi Keberanian. Surabaya : ST Book.

Sugiyono., 2009. Metode Penelitian Pendidikan Pendekatan Kuantitatif, Kualitatif, dan R\&D. Bandung: Alfabeta.

Sumaryanto, Totok., 2001. Diktat Kuliah Metodologi Penelitian Kualitatif. Semarang: IKIP Press.

Susetya, Wawan. 2007. Kepemimpinan Jawa. Yogyakarta: Narasi.

Syafiq, Muhammad. 2003. Ensiklopedia Musik Klasik. Yogyakarta: Adicita. 
Syah, Muhibbin. 2014. Psikologi Pendidikan. Bandung: PT Remaja Rosdakarya.

Tirtaraharja, U. 1990. Dasar-Dasar Kependidikan. Ujung Pandang: Bagian Penerbitan FIP IKIP Ujung Pandang. 